\title{
Editorial
}

\section{Hacer historia con la fotografía}

Este número especial que nos brinda la revista Discursos Fotográficos quiere dar cuenta de la situación de la fotografía y los estudios visuales en España en la actualidad. Algo difícil, muy difícil, ya que en los últimos años nuestra visión de lo fotográfico no ha dejado de metamorfosearse y hacerse más compleja. La fotografía, como objeto visible y tangible, permite numerosas aproximaciones teóricas y metodológicas desde diversas disciplinas, parece escaparse siempre a una formulación ontológica y se enreda, también, en nuestra vida cotidiana, ¿quién no mantiene una relación especial con una fotografía que nada tiene que ver con sus valores estéticos? ¿no queda algo en ella de ese "valor mágico que una imagen pintada ya nunca tendrá para nosotros", al que se refería Walter Benjamin?

De esta complejidad, las investigaciones actuales en España son una excelente muestra que no deja de crecer. Desde que en un texto de 1983 Joan Fontcuberta describiera la frágil consideración de esta disciplina aludiendo a "la nula conciencia del valor cultural de la fotografía en la opinión pública", a la "precariedad en la conservación del material fotográfico" o a la "negligencia por parte de los organismos competentes de la Administración" y a la "endeblez y anquilosamiento de la estructura investigadora de la Universidad española" la situación ha cambiado radicalmente.

Este monográfico, que cuenta con la participación de doce miembros de personal docente e investigador (PDI) de ocho uni- 
versidades españolas, quiere mostrar esa evolución a través de una cartografía rica en enfoques que permita, no sólo abordar las diversas problemáticas que afectan a la fotografía y los estudios visuales en España, sino trazar conexiones y espacios compartidos entre los trabajos de esas investigadoras e investigadores, teóricos y artistas. Para dibujar esta hoja de ruta, realizaremos un viaje cíclico que comenzará con un estudio en el que Francisco-José García-Ramos e Isidoro Jiménez-Gómez analizan los diez últimos años de investigación académica materializada en tesis doctorales sobre fotografía en España - donde se vislumbra la citada visión pesimista de Fontcuberta - y terminará con un texto en que el mismo Fontcuberta medita, junto a Mónica Alonso, sobre el actual orden de lo visible que nos ha dejado la era postfotográfica.

En el tránsito entre ambos, recorreremos estudios que abordan los trabajos de recuperación del patrimonio fotográfico popular, las relaciones entre la fotografía y el cine, que se inquietan por los dilemas que suscitan las nuevas tecnologías aplicadas a lo fotográfico o por las posibilidades de la práctica fotográfica en la pedagogía. Una multiplicidad de aproximaciones a lo fotográfico que no hacen sino confirmar el diagnóstico de García-Ramos y Jiménez-Gómez de que las categorías generales en que tradicionalmente se dividían las aproximaciones a lo fotográfico (Arte, Autores, Comunicación, Documentación, Historia, etc.) han de repensarse para contemplar nuevos trabajos que realizan una reflexión profunda en torno a las relaciones entre fotografía, archivo y memoria en los que el "giro material" adquiere relevancia. Estas nuevas visiones que intersecan materialidad, memoria, archivo y experiencia serán ampliamente tratadas en este número ya que suponen una de las orientaciones más 
consolidadas de la disciplina en España.

En esta línea se encuentran, precisamente, las cuatro últimas propuestas del monográfico. Jorge Moreno plantea las potencialidades de una mirada desde la antropología y lo material para acercarse a fotografías marcadas por el trauma de la represión franquista. En un texto íntimamente conectado con esta etnografía de la ausencia, Ana Pol reflexiona de la mano del trabajo de la artista coreana Theresa Hak Kyung Cha sobre los encuentros entre lo íntimo y lo público, la biografía y la(s) historia(s) a partir de la recurrencia que produce el trauma y lo espectral sobre la imagen. Gloria Durán y Álvaro Molina Alarcón prolongan la inquietud por este giro material para pensar las postales de inicios del pasado siglo XX como dispositivos de memoria. Todas estas reflexiones se dan cita en el último texto, en que Joan Fontcuberta y Mónica Alonso las hacen resonar, como un eco de los anteriores estudios. En una bien tramada conversación se enfrentan a los nuevos órdenes de lo visible de la era postfotográfica pensando la materialidad e inmaterialidad de las imágenes, la memoria y la posmemoria, las relaciones de la fotografía con la magia, el tiempo o el azar.

Sin embargo, el viaje a través de los textos, nos muestra que las nuevas perspectivas de estos últimos trabajos no dejan nunca de generar subtramas también vinculantes con otras reflexiones. Así, por ejemplo, los usos sociales de la fotografía a que dedica su texto Moreno, resuenan en el texto de Manuel Sendón en que la recuperación de la fotografía popular en la región de Galicia dibuja, en filigrana, unos usos y prácticas de la fotografía destinada a mantener unos lazos comunitarios y familiares y una memoria común a ambos lados del océano. Del mismo modo, las postales a las que dedican 
su texto Gloria Durán y Molina Alarcón entran en la vida cotidiana, transmiten imaginarios y permiten afianzar subjetividades igual que lo hacen las numerosas imágenes digitales que circulan por las redes en las que Fontcuberta encuentra utilidad para afianzar subjetividades, tender lazos y transmitir saberes, afectos y memorias. Interrogar lo fotográfico es, por tanto, interrogar la condición humana.

Pero interrogar lo fotográfico es también interrogar una trama cultural e industrial compleja y sus dimensiones y disputas éticas y jurídicas, como hace Manuel Blanco Pérez en su texto; pensar sus potencialidades narrativas cuando se inserta en otros relatos como el cinematográfico, tal como reflexiona Nekane Parejo o, incluso, pensar sus posibilidades como un instrumento de auto-exploración que puede trasladarse, como propone Isabel Soler, a las prácticas artísticas y docentes.

El conjunto de investigaciones que aquí se presentan permite extraviarse en torno a un objeto de estudio en continua mutación. Como permanente es también el mutar de estas imágenes que siguen su propia vida, despegadas de quién o qué las tomó, trastornando el tiempo, sacándolo de quicio, desquiciándolo. En sus extravíos provocan encuentros pero también propician derrumbes. Así, las fotos destinadas a salvar la distancia del exilio terminarán expuestas en un museo de arte contemporáneo, las de las cupletistas generarán fantasías en manos de quienes las miran, las fotografías de los parientes permitirán unir la historia personal y la Historia, desatarán narraciones. Este tipo de análisis apuesta por tanto por una polifonía de historia(s) que se reúnen en torno a los diversos usos de lo fotográfico que, como entre otras Abigail Solomon-Godeau, constató ya en los noventa, es quizás una de las formas más pertinentes para abordar las 
prácticas volubles y mutables — como señalábamos al comienzoque constituyen los modos de hacer fotográficos.

Francisco-José García-Ramos Universidad Complutense de Madrid.

Ana Pol-Colmenares

Universidad de Salamanca.

Mónica Alonso-Riveiro Universidad Nacional de Educación a Distancia-UNED. 